\title{
Gjeldsavleggelse på felleseieskifte
}

Tone Sverdrup er siviløkonom (1972), cand.jur. (1977) og dr. juris (1997). Hun har vært professor ved Institutt for privatrett fra 2000. Konstituert dommer i Høyesterett i tre perioder 2006-2009. E-post: tone.sverdrup@jus.uio.no

\section{Sammendrag}

I artikkelen redegjøres det for reglene om gjeldsavleggelse på skifte i ekteskapsloven § 58. Bestemmelsen er noe innfløkt formulert og har gitt opphav til flere misforståelser. To enkle grunnprinsipper ligger imidlertid til grunn for reglene, og i artikkelen redegjøres det nærmere for disse. Anvendelsen av reglene belyses med eksempler, og det tas standpunkt til enkelte tolkningsspørsmål som har stått uavklart.

Nøkkelord: fradrag for gjeld, skifteoppgjør, felleseie, ektefeller, skjevdeling, gjeld, studielån, verdimessig oppgjør

1. Hva er gjeldsavleggelse?

2. Kort oversikt over skifteoppgjøret 3

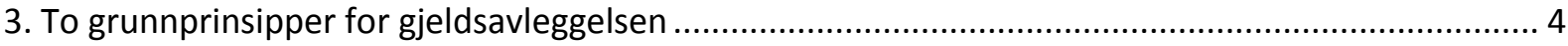

4. Ektefeller som bare har felleseiemidler som ikke skal skjevdeles ................................................ 6

5. Ektefeller som har særeie eller skjevdelingsmidler................................................................ 7

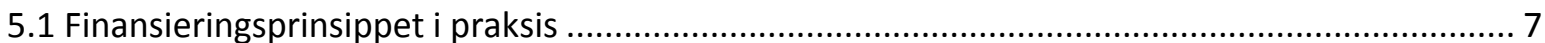

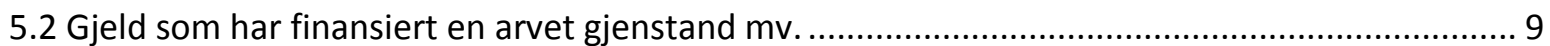

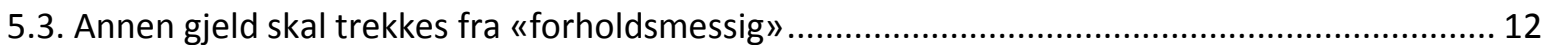

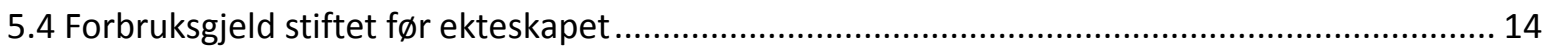

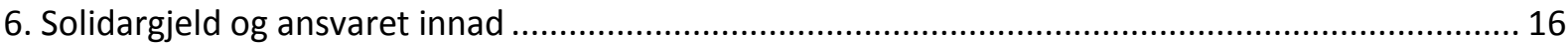

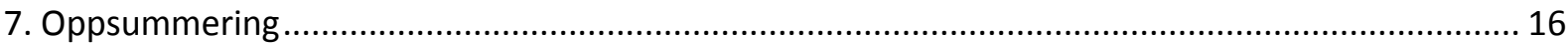

\section{Hva er gjeldsavleggelse?}


På felleseieskifte har ektefellene rett til å gjøre fradrag for gjeld før noe går til likedeling - det kalles gjerne for gjeldsavleggelse. Ikke all gjeld kan trekkes fra; de nærmere reglene finnes i ekteskapsloven (el.) § 58. Hovedprinsippene for gjeldsavleggelsen har stått uforandret siden 1927, men nye spørsmål har oppstått, først og fremst i kjølvannet av skjevdelingsregelen som ble innført i $1991 .{ }^{1}$

Felleseie er lovens normale formuesordning og innebærer at ektefellens nettoverdier kan deles likt ved ekteskapets opphør, jf. el. § 58 første ledd. Den andre formuesordningen - særeie - må avtales av ektefellene eller bestemmes av giver eller arvelater. For en ektefelle som har fullstendig særeie, blir det ikke aktuelt å foreta noen gjeldsavleggelse ettersom ektefellene da beholder hele sin formue udelt ved ekteskapets opphør. Når det ikke skjer noen deling (i betydning likedeling) av verdier, blir det heller ikke aktuelt med noen gjeldsavleggelse. Men for alle ektefeller som har felleseiemidler, oppstår spørsmålet om gjeldsavleggelse, og for disse ektefellene vil all gjeld være underlagt reglene i $\S 58$. Bestemmelsen er med andre ord «heldekkende» $i$ den forstand at all gjeld omhandles $i$ paragrafen. Et vilkår er riktignok at gjelden er stiftet før skjæringstidspunktet i el. § 60 tredje ledd; gjeld som er stiftet etter samlivsbruddet, eventuelt etter tidspunktet for begjæring av separasjon, er skiftet uvedkommende.

Det overordnede spørsmålet er hvor stor del av ektefellens gjeld som kan føres til fradrag i de midlene som skal gå til likedeling. Fordi det er nettoformuen som skal deles likt ved ekteskapets opph $\varnothing$, vil en ektefelle normalt ha et ønske om at flest mulig gjeldsposter skal kunne trekkes fra på skiftet. Dess større del av felleseiemidlene som kan holdes tilbake til dekning av gjelden, dess mindre vil gå til likedeling fra denne ektefellen.

Gjeldsavleggelse innebærer altså at ektefellen kan holde tilbake felleseiemidler til dekning av gjelden sin. Gjelden kan være forfalt eller uforfalt. At en ektefelle får anledning til å føre gjelden til fradrag $\mathrm{i}$ midlene som ellers ville gått til likedeling, innebærer altså ikke at gjelden må betales, og heller ikke at det avsettes midler på særskilte konti eller lignende. Gjeldsavleggelsen er en rent regnskapsmessig operasjon som har til formål å finne ut hvor store verdier som skal gå til likedeling fra vedkommende ektefelle.

I artikkelen skal det redegjøres nærmere for reglene som styrer gjeldsavleggelsen, og det tas standpunkt til noen tolkingsspørsmål som fremdeles står uavklarte. Men først en kort oversikt over skifteoppgjøret.

\footnotetext{
${ }^{1}$ Forarbeider til reglene om gjeldsavleggelse finnes i NOU 1987: 30 s. 76 f., s. 92 og s. 126-129, og i Ot.prp. nr. 28 (1990-91) s. 71 og s. 119-120. Reglene er omtalt i flere bøker, blant annet i Holmøy og Lødrup, Ekteskapsloven og enkelte andre lover med kommentarer, 2. utgave Oslo 2001, s. 373 f., og Lødrup og Sverdrup, Familieretten, 8. utgave Oslo 2016, s. 282 f. Se også Eeg, Deling av ektefellers formuer, Bergen 2006, s. 275 f., og Strøm Bull, Avtaler mellom ektefeller, Oslo 1993, s. 52 f. Henvisninger til artikler finnes underveis i teksten.
} 


\section{Kort oversikt over skifteoppgjøret}

Skifte betyr deling, og selve skifteoppgjøret består av to elementer. For det første et verdimessig oppgjør som bestemmer hvor mye hver ektefelle får av verdier målt i kroner og øre, jf.

ekteskapsloven kapittel 12 og $\S 77$. Dernest et gjenstandsmessig oppgjør som avgjør hvilke eiendeler den enkelte skal overta, jf. kapittel 13. Den ektefellen som får eiendeler som er mer verdt enn det hun eller han skal ha etter det verdimessige oppgjøret, må betale den andre ektefellen det overskytende, jf. § 70 første ledd. På den måten blir det harmoni mellom det verdimessige og det gjenstandsmessige oppgjøret.

Det hersker avtalefrihet under skifteoppgjøret, jf. el. § 65. Hvis ektefellene blir enige, kan de fritt avtale hvordan oppgjøret skal være, og det eksisterer heller ingen formkrav for slike avtaler.

Gjeldsavleggelsen er en del av det verdimessige oppgjøret, og i det følgende er det bare dette oppgjøret som omtales. Selv om ektefellene er underlagt formuesordningen felleseie, eier ektefellene hver sin formuesmasse og er ansvarlige for hver sin gjeld under ekteskapet, jf. el. § 31 første ledd og el. § 41. Prinsippet om to atskilte formuesmasser under ekteskapet setter også sitt preg på selve skifteoppgjøret. Det må foretas to separate oppgjør, ett for hver av ektefellene. Først må vi finne ut hvor store verdier en ektefelle eier som er felleseie - kalt brutto rådighetsdel. Hver av ektefellene kan i sin brutto rådighetsdel gjøre fradrag for tre ulike poster. For det første klær, smykker, pensjonsrettigheter mv. hjemlet i den såkalte forloddsregelen i el. § 61, deretter skjevdelingskrav etter $\S 59$, og til sist kan ektefellen holde tilbake verdier til dekning av gjelden etter $\S 58$. Når ektefellen har trukket fra disse verdiene, kommer vi frem til ektefellens netto rådighetsdel (NR), og det er dette beløpet som går inn til likedeling.

Skjematisk vil det verdimessige skifteoppgjøret se slik ut: 


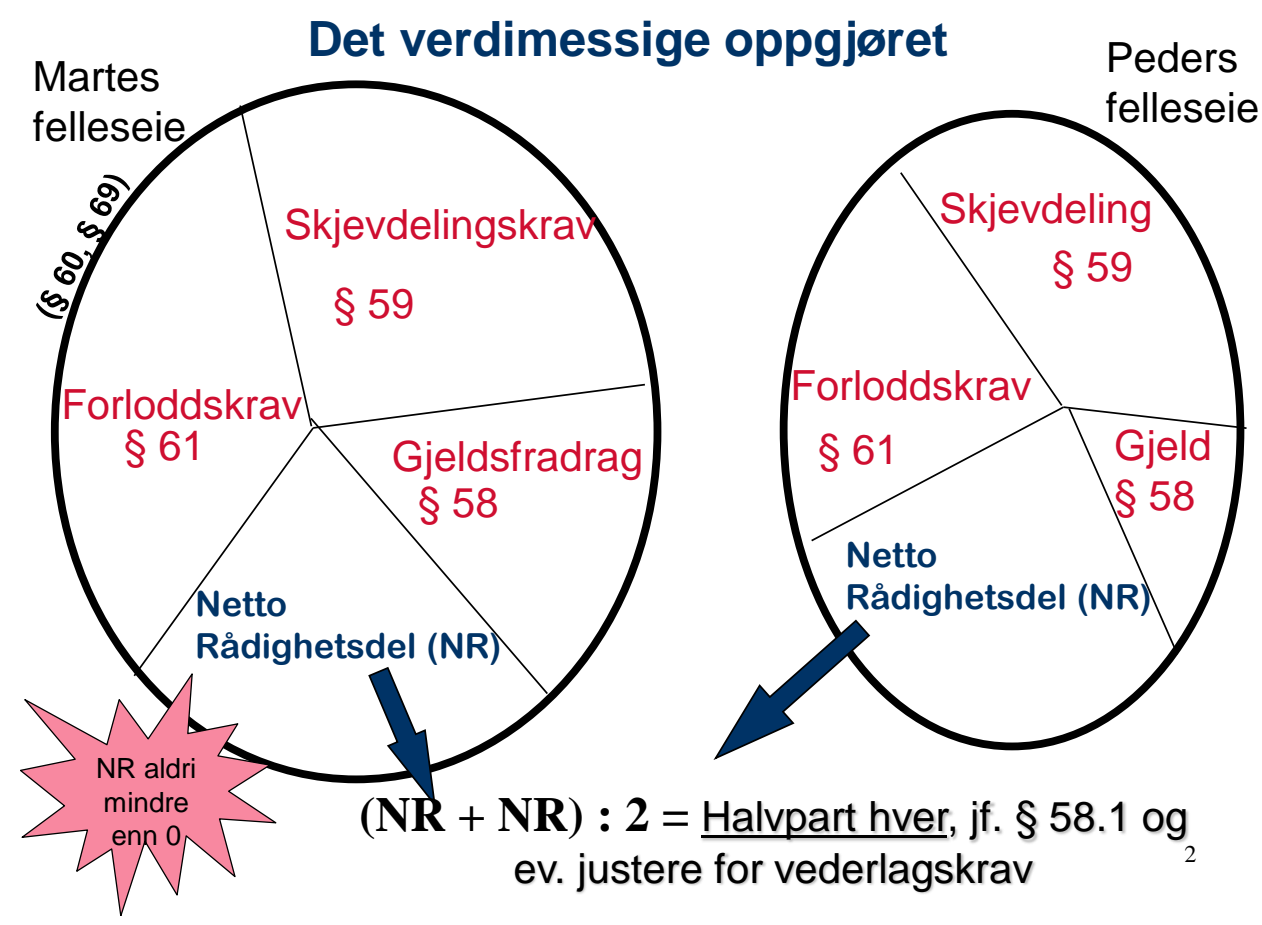

En ektefelles netto rådighetsdel kan aldri være mindre enn null, jf. også ordlyden «sin del» i § 58 annet ledd. Dette betyr at ektefeller som har større gjeld enn formue, ikke kan føre et minusbeløp inn i den summen som skal likedeles. Rent teknisk kan det forklares med at det ikke er mulig for en ektefelle å holde tilbake større verdier enn vedkommende eier. Bak dette igjen ligger prinsippet om at den ene ektefellen ikke skal måtte betale den andres gjeld - verken under ekteskapet eller ved skifteoppgjøret. Indirekte vil en ektefelle riktignok rammes økonomisk når den andre er $\mathrm{i}$ underbalanse; den «rike» ektefellen må jo gi fra seg halvparten av sin netto rådighetsdel uten å få noe igjen fra den andre.

Alle felleseieverdier skal i prinsippet verdsettes, jf. el. § 69, men i praksis er det vanligvis ikke nødvendig å verdsette gjenstander som ektefellen tar ut forlodds etter § 61 (klær, smykker, pensjonsrettigheter mv.) ettersom ektefellen etter denne forloddsregelen får beholde både selve eiendelen og verdien av den.

\section{To grunnprinsipper for gjeldsavleggelsen}

Gjeldsavleggelsesregelen i § 58 har følgende ordlyd:

§ 58 Ektefellenes samlede formuer skal som utgangspunkt deles likt etter at det er gjort fradrag for gjeld etter andre og tredje ledd (felleseie). Er ektefellene sammen ansvarlig for gjeld, kan hver gjøre fradrag for den delen som faller på ham eller henne etter forholdet mellom ektefellene. 
En ektefelle som bare har formue som er felleseie, og som ikke holder midler utenfor delingen etter $\S 59$, kan i sin del fullt ut gjøre fradrag for den gjelden han eller hun har.

En ektefelle som har særeie, eller som holder midler utenfor delingen etter $\$ 59$, kan gjøre følgende fradrag for gjeld i formue som er felleseie:

a. Gjeld som ektefellen har pådratt seg ved erverv eller påkostninger av eiendeler som er felleseie, kan det kreves fullt fradrag for hvis ikke noe annet følger av bokstav $b$.

b. Gjeld som ektefellen har pådratt seg ved erverv eller påkostninger av eiendeler som er særeie eller verdier som holdes utenfor delingen etter \$59, kan det bare kreves fradrag for når den totale verdien av særeie og skjevdelingsmidlene ikke er stor nok til å dekke gjelden. Tilsvarende gjelder gjeld som ektefellen har pådratt seg ved erverv eller påkostninger av eiendeler som er unntatt fra deling etter $\S 61$ bokstav $b$ eller $c$, eller ved utilbørlig atferd i forhold til den andre ektefellen.

c. For annen gjeld kan det kreves fradrag for en forholdsmessig del.

Hjemmelen for gjeldsavleggelse må alltid finnes enten i § 58 annet eller tredje ledd. Vi ser at disse to leddene i § 58 er gjensidig utelukkende; en ektefelle kan altså ikke falle inn under både annet ledd og tredje ledd. Dersom ektefellen kun har felleseiemidler og disse felleseiemidlene heller ikke holdes utenfor etter skjevdelingsregelen i $\S 59$, faller ektefellen inn under $\S 58$ annet ledd, se pkt. 4 nedenfor. Har ektefellen derimot særeiemidler og/eller skjevdelingsmidler, faller vedkommende inn under tredje ledd, se nærmere under pkt. 5. Det er selvsagt ikke noe i veien for at den ene ektefellen i et ekteskap faller inn under annet ledd, mens den andre faller inn under tredje ledd.

Hovedregelen om likedeling angis i § 58 første ledd, og i dette leddet gis det også en spesialregel om solidargjeld, se nærmere under pkt. 6.

Gjeldsavleggelsesreglene i § 58 er noe innfløkt formulert, men blir enklere å forstå når man kjenner de to hovedprinsippene som ligger til grunn for regelen. Bestemmelsene i § 58 er utformet slik at en ektefelle ikke kan bli insuffisient, dvs. ende opp med mer gjeld enn formue som følge av skifteoppgjøret. Med andre ord: Ikke en krone går til likedeling fra en ektefelle før denne ektefellen har fått alle sine gjeldsposter dekket opp i formuen sin - det være seg i felleseie- eller særeieverdier. Dette «dekningsprinsippet» er unntaksfritt. Det andre prinsippet kan kalles finansieringsprinsippet, og innebærer at en gjeldspost primært skal føres til fradrag i den type midler som gjelden er benyttet til å finansiere. Dette prinsippet får bare aktualitet for ektefeller som har særeie eller skjevdelingsmidler, dvs. som faller inn under $\S 58$ tredje ledd. Er gjelden brukt til å erverve eller påkoste eiendeler som skal likedeles, kan ektefellen trekke gjelden fra på skiftet. Er gjelden derimot benyttet til å finansiere midler som holdes utenfor delingen, for eksempel særeieverdier, må ektefellen i første omgang gjøre fradrag i særeie- og skjevdelingsmidler som holdes utenfor delingen, jf. tredje ledd bokstav $b$. Noen gjeldsposter er ikke benyttet til å erverve eller påkoste eiendeler i det hele tatt - det er såkalt «annen gjeld» i bokstav c, og her kan ektefeller som faller inn under tredje ledd, bare trekke fra en forholdsmessig del, se nærmere under pkt. 5.3 nedenfor. 


\section{Ektefeller som bare har felleseiemidler som ikke skal skjevdeles}

For ektefeller som faller inn under annet ledd, dvs. som bare har felleseiemidler som ikke skjevdeles, er regelen for gjeldsavleggelse meget enkel. De kan «fullt ut gjøre fradrag for den gjelden» som de har - enten det dreier seg om boliggjeld, studiegjeld eller andre typer gjeld. Regelen er et utslag av dekningsprinsippet: Ingen ektefelle skal komme i minus, dvs. bli insuffisient, som følge av en skilsmisse, og derfor må all gjeld kunne trekkes fra før noe går til likedeling.

Bestemmelsen i annet ledd må tas på ordet. Selv om ektefellen holder felleseiemidler utenfor delingen i medhold av forloddsregelen i el. § 61, kan all gjeld - også gjeld som er brukt til å kjøpe selve forloddsrettigheten - trekkes fra på skifte. Noen vil kanskje mene at det er lite rimelig at en ektefelle både får holde eiendelen, for eksempel en pensjonsforsikring, utenfor delingen og samtidig trekke fra gjelden som er brukt til å kjøpe pensjonsforsikringen. Men dette er et valg lovgiver har tatt, og må sees i lys av at eiendeler og rettigheter i el. § 61 i noen grad er utleggsfrie midler, se dekningsloven kapittel 2. ${ }^{2}$ Dessuten kan vederlagsreglene i el. § 63 komme den andre ektefellen til hjelp i slike tilfeller. La oss tenke oss at konen tar opp lån for å kjøpe en pensjonsforsikring. Denne har hun rett til å holde utenfor delingen etter $\S 61$ bokstav b. I den utstrekning lånet står ubetalt på skiftetidspunktet, kan hun trekke fra gjelden i de midlene som ellers ville gått til likedeling, så sant hun faller inn under $\S 58$ annet ledd, dvs. så sant hun verken har særeie- eller skjevdelingsmidler. Det følger direkte av ordlyden i annet ledd. Dermed får hun på et vis i pose og sekk: Pensjonsforsikringen blir ikke delt, og hun får holde tilbake sine øvrige felleseiemidler til dekning av gjelden som er brukt til å kjøpe den. Men heldigvis er det ikke så enkelt å holde midler utenfor delingen. Ektemannen kan i dette tilfellet tilkjennes vederlag i medhold av $\S 63$ første ledd siste punktum. Konen har «brukt felleseiemidler» på skiftet, og virkningen blir helt den samme som om hun hadde brukt oppsparte likedelingsmidler til å kjøpe pensjonsforsikringen under ekteskapet. I begge tilfeller er hennes netto rådighetsdel redusert sammenlignet med hva den ellers ville ha vært; det går altså mindre til likedeling fra henne. Før vedtakelsen av ekteskapsloven hadde ektemannen i slike tilfeller en ubetinget rett til vederlag etter skifteloven $\S 49$. Det følger av forarbeidene til el. $\S 63$ at det ikke var tilsiktet noen realitetsendring, selv om uttalelsene ikke er helt klare med hensyn til videreføringen av skifteloven § 49 i el. § 63 første ledd. ${ }^{3}$ Det må likevel være klart at gjeldsavleggelse på skiftet nå faller inn under «brukt felleseiemidler» i § 63 første ledd. Kompensasjonsreglene som finnes i § 61 bokstav b og c, kan også benyttes i en del tilfeller. Her er det ikke noe vilkår at ektefellen aktivt har brukt likedelingsmidler til å øke verdien av forloddsrettighetene, men til gjengjeld må den andre ektefellen ha blitt «urimelig dårlig stilt». I noen tilfeller kan det også være aktuelt med vederlag etter regelen om utilbørlig svekkelse av delingsgrunnlaget i § 63 annet ledd. Dersom konen i vårt eksempel har kjøpt en pensjonsforsikring for lånte midler i den hensikt å redusere sin likedelingsformue ved en nært forestående skilsmisse, kan det vurderes som en illojal tapping av formuen og derved rammes av utilbørlighetsregelen i § 63 annet ledd.

\footnotetext{
${ }^{2}$ Se også omtale hos Holmøy og Lødrup, Ekteskapsloven og enkelte andre lover med kommentarer, 2. utgave Oslo 2001, s. 380-381.

${ }^{3}$ Se Ot.prp. nr. 28 (1990-91) s. 123 og NOU 1987: 30 s. 134, jf. Lødrup og Sverdrup, Familieretten, 8. utgave Oslo 2016, s. 294-295.
} 


\section{Ektefeller som har særeie eller skjevdelingsmidler}

\subsection{Finansieringsprinsippet i praksis}

Ektefeller som holder særeie eller skjevdelingsmidler utenfor delingen, faller inn under § 58 tredje ledd. For disse ektefellene gjelder finansieringsprinsippet; gjeldsavleggelsen beror på hva den enkelte gjeldsposten er benyttet til å finansiere: Gjeld som er brukt til erverv eller påkostning av eiendeler som skal likedeles, kan trekkes fra fullt ut på skiftet, jf. tredje ledd bokstav a. Er gjelden derimot brukt til finansering av særeieverdier mv., må ektefellen først dekke opp gjelden i særeie- og skjevdelingsmidlene, og bare hvis disse ikke strekker til, kan gjelden føres til fradrag i likedelingsmidlene, jf. bokstav $b$. Vi ser at finansieringsprinsippet må vike for at dekningsprinsippet skal være unntaksfritt.

La oss se på et tilfelle hvor det er avtalt at ektemannens landsted verdt 4 millioner kroner skal være hans særeie. Landstedet ble i sin tid ervervet ved låneopptak på 3 millioner kroner og egenkapital på 1 million kroner. Ett år etter kjøpet bygges det en motorvei tett ved, og landstedets verdi halveres som følge av dette. Ekteskapet går samtidig mot slutten, og ved skilsmissen har ektemannen ingen andre særeie- eller skjevdelingsverdier enn nettopp landstedet, som nå er verdt 2 millioner kroner. Lånet står fremdeles til rest med 3 millioner kroner, og etter regelen i § 58 tredje ledd bokstav b må ektemannen først dekke opp lånet i summen av særeie- og skjevdelingsmidler. Beløpet er imidlertid ikke stort nok, og den siste millionen av gjelden får han derfor føre til fradrag på skiftet i likedelingsmidlene sine, jf. tredje ledd bokstav b. Slik må regelen være for at ektemannen ikke skal bli insuffisient som følge av skifteoppgjøret.

Helt til sist i § 58 tredje ledd bokstav b heter det at «[t]ilsvarende gjelder» for gjeld som ektefellen har pådratt seg ved erverv eller påkostninger av eiendeler som er unntatt fra deling etter el. § 61 bokstav b eller $\mathrm{c}$ - for eksempel pensjonsrettigheter. Uttrykket «tilsvarende gjelder» er ikke krystallklart, men det vises her til at slik gjeld kan trekkes fra i summen av særeie- og skjevdelingsmidlene. Selve forloddsrettighetene i bokstav b og c skal heller ikke etter tredje ledd benyttes til gjeldsavleggelse. Urimeligheter som kan oppstå i den forbindelse, kan avhjelpes gjennom vederlagsreglene, se nærmere omtale under pkt. 4 ovenfor.

Gjeld som ikke er benyttet til noe av de formålene som er nevnt i bokstav a og b - såkalt «annen gjeld» - kan føres delvis til fradrag ut fra det st $\varnothing$ rrelsesmessige forholdet mellom likedelingsmidler og særeie-/skjevdelingsmidler, jf. tredje ledd bokstav c, se pkt. 6 nedenfor.

Det følger av ordlyden i tredje ledd bokstav $b$ at gjeld som er benyttet til å erverve andre forloddsrettigheter enn dem som er nevnt i el. § 61 bokstav b og c, ikke trenger å føres til fradrag i særeie- og skjevdelingsmidlene. Gjelden som er brukt til erverv av eiendeler som utelukkende tjener til personlig bruk etter bokstav a, kan derfor føres til fradrag på skiftet etter tredje ledd bokstav a. Konen har for eksempel kjøpt en smykkesamling for lånte midler som hun krever holdt utenfor 
delingen etter $\S 61$ bokstav a. Selv om hun har særeie og skjevdelingsmidler, kan hun trekke fra smykkelånet i likedelingsmidlene. Hvis det er snakk om smykker av betydelig verdi, kan denne Iøsningen synes urimelig. Her finnes imidlertid sikkerhetsventilen i § 61 bokstav a: Hun får ikke holde smykkene utenfor delingen dersom det vil være «åpenbart urimelig».

Det følger direkte av ordlyden i § 58 tredje ledd at det avgjørende er om lånet er benyttet til erverv eller påkostning av en eiendel; hvorvidt lånet er sikret ved pant i eiendelen, er dermed uten betydning for gjeldsavleggelsen. Det har selvsagt heller ingen betydning for gjeldsavleggelsen hva lånet er benevnt som - om det heter «boligkreditt», «flexilån», "forbrukslån», «rammelån» osv. Det avgjørende er hva gjelden rent faktisk er benyttet til å finansiere. Ektemannen tar for eksempel opp et «flexilån» på 1 million kroner med pant i boligen og bruker 700000 kroner til boligkjøpet mens 300000 kroner benyttes til dekning av løpende forbruksutgifter. Boligen består av felleseiemidler som skal likedeles, og mannen faller inn under tredje ledd fordi han også har særeie. Hvis hele lånet fremdeles står ubetalt på skiftetidspunktet, vil 700000 kroner trekkes fra i hans likedelingsmidler etter bokstav a, mens 300000 kroner av gjelden går til fradrag med en «forholdsmessig del» etter $\S$ 58 tredje ledd bokstav c. Dersom deler av flexilånet er nedbetalt under ekteskapet og for eksempel står til rest med 500000 kroner, er det naturlig å anta at restlånet fordeler seg på bolig og forbruk med det opprinnelige forholdstall, slik at 70 prosent av restlånet (her 350000 kroner) anses for å ha gått til erverv av boligen, og 30 prosent (150 000 kroner) til forbruk.

Også utgifter til alminnelig vedlikehold av bolig, hytte osv. skal ifølge forarbeidene regnes som «påkostning». ${ }^{4}$ Ordinære vedlikeholdsutgifter regnes ellers i ekteskapsloven som forbruk, det er snakk om utgifter som er nødvendige for å opprettholde boligverdier - ikke øke dem.

Dersom lånet er benyttet til erverv eller påkostning av en gjenstand som senere har gått til grunne, er lånesummen i realiteten forbrukt, og i utgangspunktet dreier det seg da om «annen gjeld» som faller inn under tredje ledd bokstav c. Det kan for eksempel være snakk om et lån som er brukt til kjøp av en båt. Under ekteskapet brenner båten uforsikret, slik at det heller ikke finnes surrogater i boet på skiftetidspunktet. Hvis gjenstanden har gått til helt grunne, kan det etter mitt syn være naturlig å benytte regelen i tredje ledd bokstav c, fordi det nå i realiteten er snakk om forbruksgjeld som bør fordeles forholdsmessig. Det kan imidlertid argumenteres med at et slikt resultat fører til uheldige terskeleffekter: Hvis båten bare har sunket sterkt i verdi uten at den har gått helt til grunne, måtte ektefellen ha dekket opp restgjelden i særeie- og skjevdelingsmidlene så langt de strakk til. Uansett hvilken løsning som her velges, må det gjøres unntak for gjeld pådratt «ved utilbørlig adferd i forhold til den andre ektefellen». I slike tilfeller må ektefellen først søke dekning i særeie- og skjevdelingsmidlene; det følger av tredje ledd bokstav b siste punktum. Unnlatelse av å forsikre verdifulle eiendeler kan etter omstendighetene være en slik «utilbørlig» adferd; det samme gjelder gaver gitt i den hensikt å tappe boet i forbindelse med en nært forestående skilsmisse.

\footnotetext{
${ }^{4}$ I Ot.prp. nr. 28 (1990-91) s. 120 sies det at begrepet «påkostning» i loven tilsvarer begrepet «forøkelse» skifteloven $\S 45$ andre ledd. Videre heter det: «For eksempel må vedlikehold omfattes.»
} 
Vederlagsreglene i el. § 63 første og annet ledd kan også bøte på urimeligheter som oppstår når ektefellen får trekke fra gjelden helt eller delvis i likedelingsmidlene i saker hvor selve eiendelen har gått til grunne eller er gitt bort.

\subsection{Gjeld som har finansiert en arvet gjenstand mv.}

I $\$ 58$ tredje ledd bokstav $b$ heter det at gjeld som ektefellen har pådratt seg ved erverv eller påkostninger av «verdier som holdes utenfor delingen etter § 59», bare kan kreves fradrag for når den totale verdien av særeie- og skjevdelingsmidlene ikke er stor nok til å dekke gjelden. Denne uttrykksmåten er forvirrende ettersom slik gjeld nærmest per definisjon ikke kan forekomme. Skjevdelingskravet er jo et nettokrav, jf. Rt. 2002 s. 1596, slik at opprinnelig gjeld er trukket fra i det beløpet som holdes utenfor delingen i medhold av $\S 59 .{ }^{5}$ Det skal derfor ikke finnes gjeld som er benyttet til å finansiere verdier som holdes utenfor etter skjevdelingsregelen. La oss tenke oss at konen eier et hus til 1 million kroner som hun i sin tid fikk i arv fra sine foreldre mot å overta pantegjelden på 800000 kroner. Huset har verken steget eller sunket i verdi siden hun mottok det.

Da blir hennes skjevdelingskrav på 200000 kroner. Resten av husets verdi på 800000 kroner er altså likedelingsmidler. Hvorvidt huslånet er nedbetalt under ekteskapet, er irrelevant for skjevdelingskravets størrelse som uansett er på 200000 kroner. (Jeg forutsetter da at lånet ikke er nedbetalt med andre skjevdelingsmidler, for eksempel en ny arv som gir opphav til et nytt skjevdelingskrav.) Men hvorvidt lånet på 800000 kroner er nedbetalt eller ikke, har selvsagt betydning for hvor mye som kan føres til fradrag etter $\S 58$ tredje ledd. La oss forutsette at 450000 kroner av lånet er nedbetalt under ekteskapet med kvinnens inntekt. Restgjelden på 350000 kroner er benyttet til å finansiere likedelingsmidlene i det arvede huset, og dermed skal denne gjelden trekkes fra fullt ut på skiftet etter $\S 58$ tredje ledd bokstav a.

Hvis vi tenker oss at ektefellen bare eier dette huset, kan gjeldsavleggelsen illustreres slik:

\footnotetext{
${ }^{5}$ Se Sverdrup, Stiftelse av sameie i ekteskap og ugift samliv, Oslo 1997, s. 25, i note 47, jf. også Holmøy og Lødrup, Ekteskapsloven og enkelte andre lover med kommentarer, 2. utgave Oslo 2001, s. 379, i note 14 og Sverdrup, «Skjevdeling på felleseieskifte - noen uavklarte spørsmål», i Bull, Hagstrøm og Tjomsland (red.), Bonus Pater Familias. Festskrift til Peter Lødrup, Oslo 2002, s. 679, i note 11. Strandbakken slutter seg til synspunktet i «Gjeldsfradrag ved skjevdeling - noen refleksjoner etter Rt. 2002 s. 1596», FAB 2/2003 s. 110, jf. også Frantzen, "Skjevdeling - nye regler til besvær», FAB 3-4/2003, s. 232 og s. 236. Spørsmålet om skjevdeling var et netto- eller bruttokrav var for $\varnothing$ vrig omtvistet i teorien frem til 2002-dommen, se en informativ redegjørelse for diskusjonen hos Berg-Jacobsen, «Beregning av skjevdelingskrav», i FAB 3/2011 pkt. 2.
} 


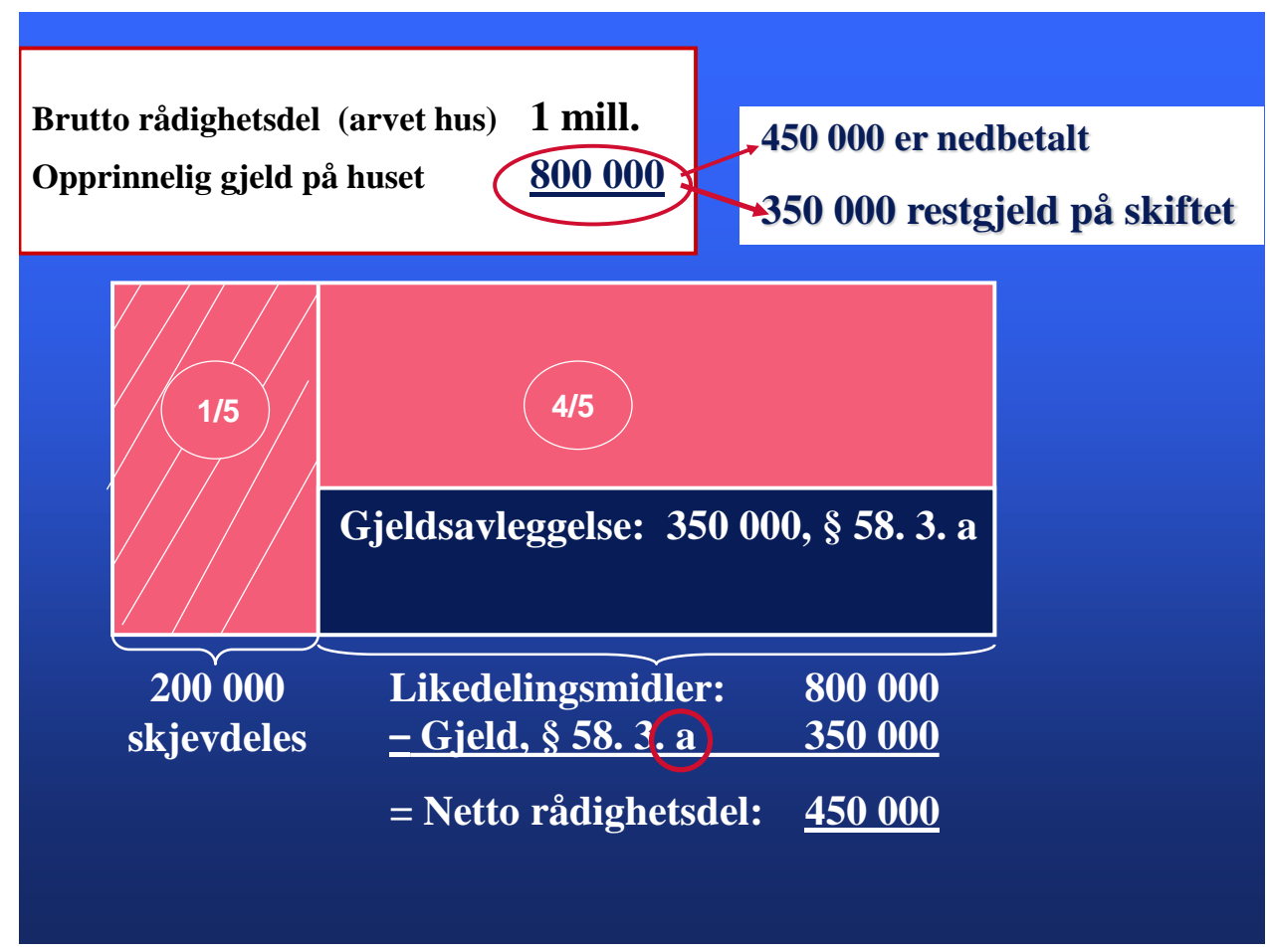

Dersom restgjelden skulle vært trukket fra i skjevdelingsmidlene etter $\S 58$ tredje ledd bokstav b, måtte skjevdelingskravet være et bruttokrav. Skjevdeling er imidlertid som nevnt et nettokrav. Den lånefinansierte delen av det arvede huset (her 4/5-deler eller 80 prosent) er derfor likedelingsmidler. I utgangspunktet er gjelden (per definisjon) ikke pådratt ved erverv/påkostning av skjevdelingsmidler, men av likedelingsmidler, og skal da trekkes fra på skiftet etter $\S 58$ tredje ledd bokstav a. I praksis vil det sjelden kunne forekomme gjeld som faller inn under beskrivelsen i § 58 tredje ledd bokstav $\mathrm{b}$.

Ett tilfelle kan riktignok konstrueres: Har ektefellen arvet en hytte og bruker lønnsinntekt til å vedlikeholde hytta, får ektefellen likevel normalt skjevdelt nåverdien av hytta, inkludert verdier som kan føres tilbake til vedlikeholdet, så sant det er snakk om alminnelig vedlikehold som bare opprettholder verdiene i hytta, og ikke øker dem. ${ }^{6}$ La oss tenke oss en slik situasjon, men hvor ektefellen i stedet for å bruke inntekten sin til alminnelig vedlikehold har tatt opp et lån. Ifølge proposisjonen skal et slikt lån regnes for å være brukt til påkostning, og dermed føres til fradrag i

\footnotetext{
${ }^{6}$ I NOU 1987: 30 s. 83 pekes det på at hvor de opprinnelige eiendelene er i behold når samlivet heves, «er det deres aktuelle verdi som skal legges til grunn, med mindre det foreligger en verdiøkning på grunn av forbedringer e.l., jfr. ovenfor». Hvorvidt alminnelig vedlikehold som bare opprettholder verdier, og ikke øker dem, aldri skal trekkes fra i skjevdelingskravet, kan diskuteres, se drøftelse hos Sverdrup, «Skjevdeling på felleseieskifte - noen uavklarte spørsmål», i Bull, Hagstrøm og Tjomsland (red.), Bonus Pater Familias. Festskrift til Peter Lødrup, Oslo 2002, s. 692. Se også Holmøy og Lødrup, Ekteskapsloven og enkelte andre lover med kommentarer, 2. utgave, Oslo 2001, s. 390, Lødrup og Sverdrup, Familieretten, 8. utgave Oslo 2016 og Holmøy, «Om skjevdeling», LoR s. 30.
} 
særeie- og skjevdelingsmidlene i § 58 tredje ledd bokstav b. ${ }^{7}$ Følger vi proposisjonens bud om at «påkostninger» i $\S 58$ tredje ledd også omfatter alminnelig vedlikehold, har vi en situasjon som faller inn under den «umulige» ordlyden i tredje ledd bokstav b, dvs. gjeld som er brukt til påkostning av skjevdelingsmidler.

Prinsippene for gjeldsavleggelse blir de samme om den arvede boligen i eksempelet ovenfor har steget eller sunket i verdi frem til skiftetidspunktet. Når en skjevdelingseiendom stiger i verdi som følge av markedssvingninger, skal en forholdsmessig del av verdistigningen skjevdeles, jf. Rt. $2002 \mathrm{~s}$. 1596. I den saken eide ektemannen en bolig hvor 48,3 prosent besto av egenkapital ved ekteskapsinngåelsen, og han fikk skjevdelt den samme prosentandelen av boligens nåverdi på skiftetidspunktet.

Det er altså den opprinnelige gjeldsbelastningen som har interesse for skjevdelingskravets størrelse. For å finne frem til hvor stor del av boligen som skal skjevdeles, må vi regne ut hvor stor prosent eller brøk av boligen som var nedbetalt på ervervstidspunktet. I vårt eksempel er 4/5-deler eller 80 prosent av boligen likedelingsmidler og 1/5-del eller 20 prosent er skjevdelingsmidler. Tenker vi oss at huset på skiftetidspunktet har steget til 1,6 million kroner, blir konens skjevdelingskrav på 20 prosent av nåverdien på 1,6 million kroner, dvs. 320000 kroner. Gjeldsavleggelsen skal også nå skje i de 80 prosentene av eiendommen som er likedelingsmidler, jf. tredje ledd bokstav a. Hennes netto rådighetsdel blir da på 930000 kroner.

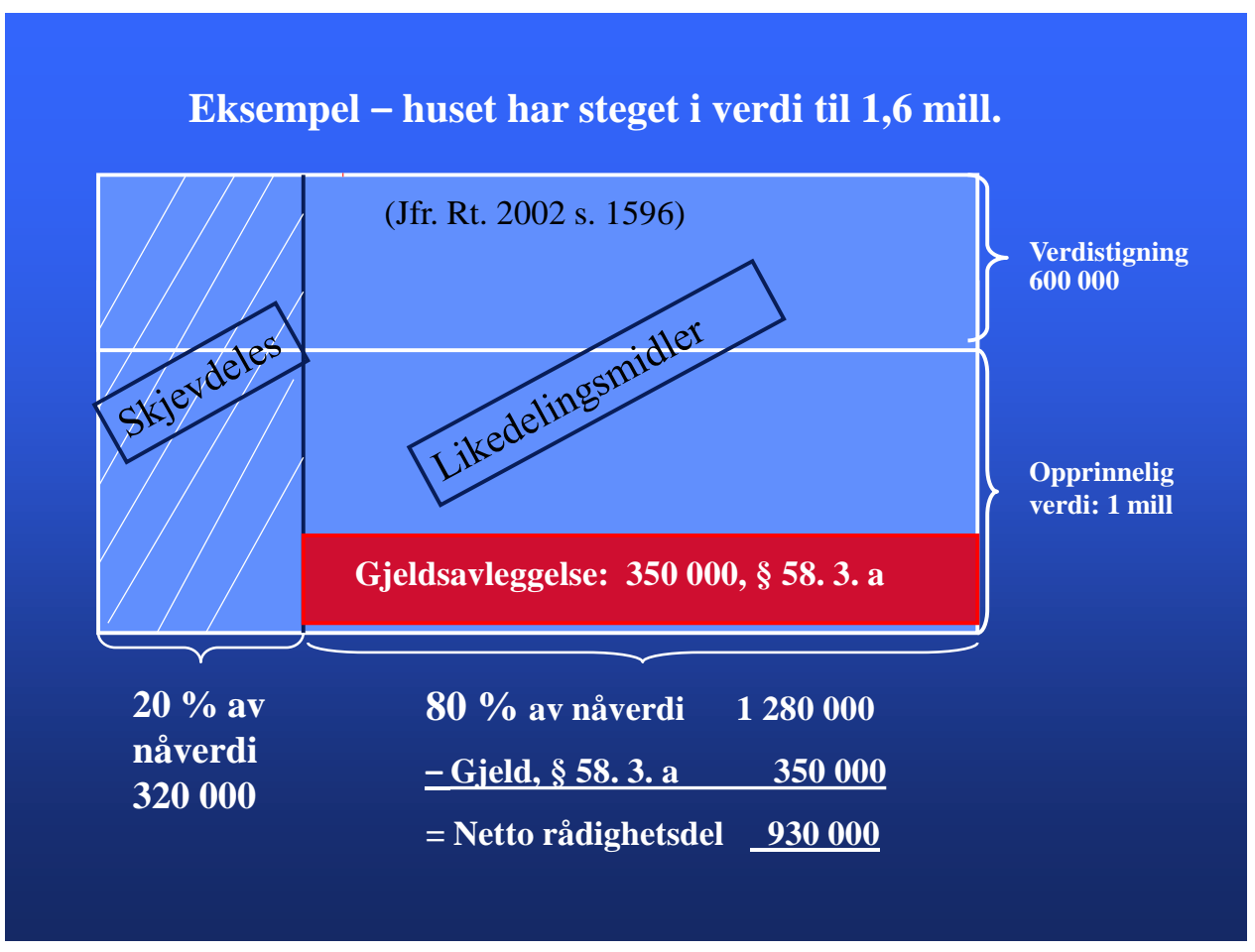

\footnotetext{
${ }^{7}$ Ot.prp. nr. 28 (1990-91) s. 120, jf. omtale ovenfor under pkt. 5.1.
} 
Den samme forholdsmessige vurdering må foretas dersom eiendelen har sunket $\mathrm{i}$ verdi. La oss ta utgangspunkt i samme eksempel som ovenfor, hvor huset var verdt 1 million kroner ved ekteskapsinngåelsen, og opprinnelig gjeld var på 800000 kroner. På skiftetidspunktet forutsetter vi at huset har sunket i verdi til 700000 kroner som følge av nedgang i boligmarkedet. Ellers er tallene for opprinnelig gjeld og restgjeld de samme som i forrige eksempel. Ved å benytte det samme prinsippet som i Rt. 2002 s. 1596 vil konens skjevdelingskrav utgjøre 20 prosent av nåverdien på 700000 kroner, dvs. 140000 kroner, og likedelingsmidlene i huset blir da på 560000 kroner. Restgjelden på 350000 kan trekkes fra på skiftet i disse likedelingsmidlene, jf. § 58 tredje ledd bokstav a. Konens netto rådighetsdel beløper seg da til 210000 kroner.

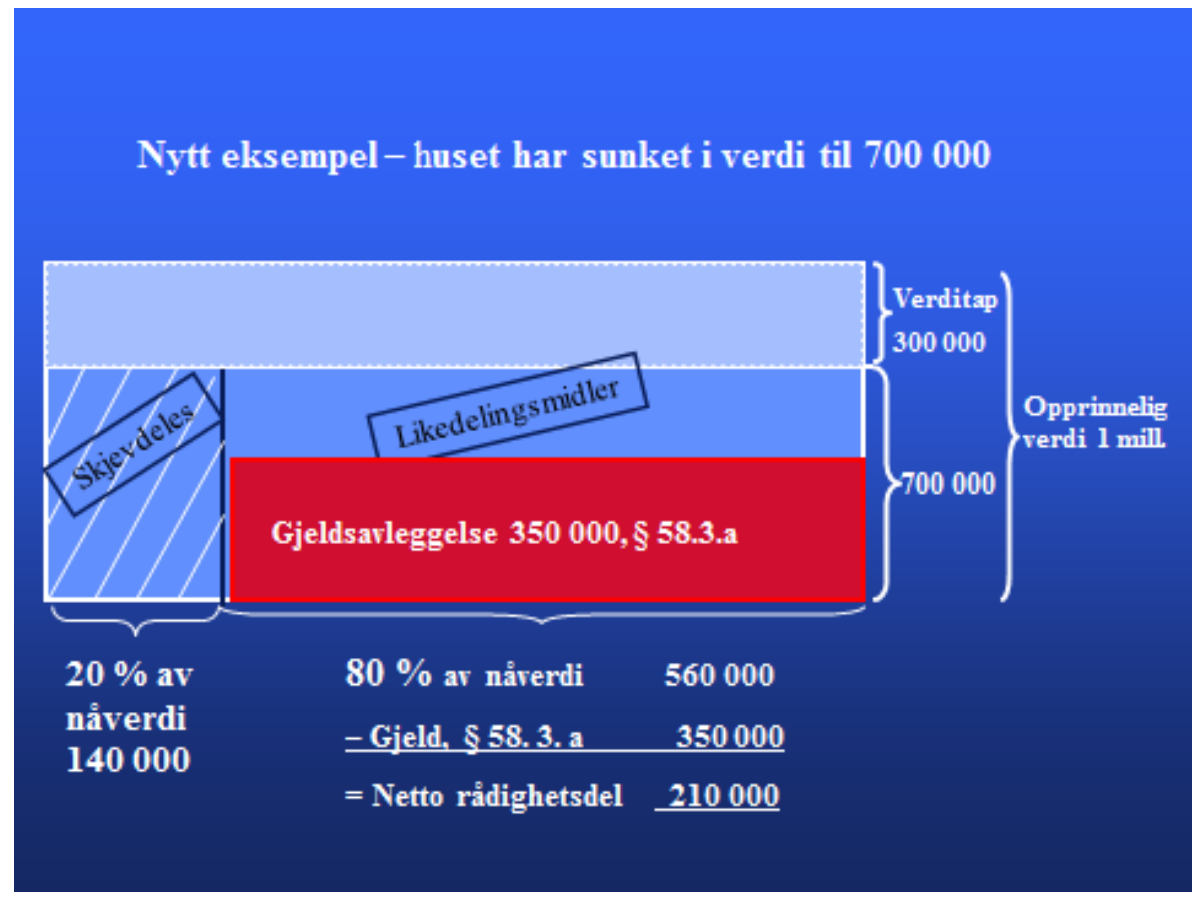

\subsection{Annen gjeld skal trekkes fra «forholdsmessig»}

Reglene i § 58 tredje ledd innebærer som nevnt at gjelden skal trekkes fra i den typen midler den er benyttet til å finansiere. Dette finansieringsprinsippet kan imidlertid ikke benyttes i de tilfellene hvor lånet ikke er brukt til å finansiere noen eiendeler. Et typisk eksempel er studiegjeld som har gått til dekning av løpende forbruksutgifter. Andre eksempler er bidragsgjeld, kausjonsforpliktelser, restskatt og erstatningskrav. Før 1991-loven kunne slik gjeld trekkes fra fullt ut på skiftet, selv om ektefellen holdt store særeiemidler utenfor delingen. Ekteskapslovutvalget fant imidlertid at forbruksgjelden burde belaste flere typer midler som ektefellen hadde. Nå har $\S 58$ tredje ledd bokstav c følgende regel: «For annen gjeld kan det kreves fradrag for en forholdsmessig del.»

Med «annen gjeld» siktes det her til gjeld som ikke faller inn under bokstav a eller b, altså gjeld som ikke er benyttet til å erverve eller påkoste noen eiendeler. Det følger av ordlyden i bokstav c at bare 
en forholdsmessig del - dvs. en bestemt brøkdel eller prosentdel - av slik forbruksgjeld skal trekkes fra på skiftet. Det er ikke mulig å slutte fra lovens ordlyd hva som nærmere menes med "forholdsmessig del», men grunntanken bak regelen gir oss en god pekepinn, og forarbeidene belyser anvendelsen med flere eksempler. ${ }^{8}$ Med «forholdsmessig del» siktes det til det størrelsesmessige forholdet mellom likedelingsmidler på den ene siden og skjevdelingsmidler og særeienetto på den andre siden:

Netto rådighetsdel før bokstav c-gield

Netto rådighetsdel før bokstav c-gjeld + Skjevdeling + Særeienetto

Brøken beregnes ved at netto likedelingsmidler settes over brøkstreken, mens summen av netto likedelingsmidler, netto særeiemidler og skjevdelingsmidler settes under brøkstreken. Det er bare denne brøkdelen av forbruksgjelden som kan trekkes fra på skiftet.

Poenget med brøken er at forbruksgjelden skal belastes rettferdig mellom midler som går til likedeling på den ene siden, og midler som ektefellen holder utenfor delingen på den andre siden. For å oppnå en slik rettferdig fordeling må vi vite hvor stor del likedelingsmidlene utgjør av totalsummen av likedelings-, skjevdelings- og særeiemidler.

Netto likedelingsmidler er det beløpet vi står igjen med når både forloddskrav, skjevdelingsverdier og gjeldsavleggelse i medhold av $\S 58$ bokstav a og b er trukket fra i ektefellens brutto rådighetsdel. Som ellers ved gjeldsavleggelsen skal forloddsrettighetene etter $\S 61$ (klær, smykker, pensjonsrettigheter osv.) ikke brukes som objekter for gjeldsavleggelse.

Skal denne gjelden fordeles forholdsmessig rettferdig mellom likedelingsmidler og midler som er unntatt fra deling, må det opereres med nettobeløp, da det er nettoverdiene som gir uttrykk for verdipostenes evne til å bære forbruksgjelden. Over brøkstreken må likedelingsmidlene være fratrukket all gjeld som kan trekkes fra etter bokstav a og b. Tilsvarende under brøkstreken - særeiet må også være fratrukket gjelden. Om ektemannen eier et særeie-landsted til ti millioner kroner, men har en gjeld på ni millioner kroner som er benyttet til å kjøpe landstedet, er den reelle verdien av hans særeie bare én million kroner. Det er denne millionen som gir et dekkende uttrykk for særeiets evne til å bære forbruksgjelden. Gjeld benyttet til å erverve rettigheter som unntas etter $\S 61$ bokstav b og c eller ved utilbørlig adferd, skal som nevnt primært føres til fradrag i skjevdelings- og særeieverdier, jf. § 58 tredje ledd bokstav b siste punktum. Dermed vil også slik gjeld redusere det særeie- og skjevdelingsbeløpet som vi setter under brøkstreken. Skjevdelingsverdier er allerede i utgangspunktet (per definisjon) et nettobeløp ettersom det opprinnelige gjeldsbeløpet er trukket fra ved beregningen av kravet.

Et eksempel kan vise hvordan brøken beregnes. La oss tenke oss at ektemannen har en bolig som er felleseie og har en nettoverdi på 800000 kroner, hvorav intet er gjenstand for skjevdeling. Han har

\footnotetext{
${ }^{8}$ Se NOU 1987: 30 s. 128-129, jf. Ot.prp. nr. 28 (1990-91) s. 120.
} 
en hytte som er særeie og som har en nettoverdi på 400000 kroner. Dessuten har han et studielån som er benyttet til dekning av forbruksutgifter, som står til rest med 100000 kroner. Spørsmålet er hvor mye av dette studielånet som kan trekkes fra på skiftet. Siden han har særeie, faller han inn under reglene i $\S 58$ tredje ledd. Det følger av tredje ledd bokstav c at han kan trekke fra en "forholdsmessig» del av studiegjelden, det vil si en så stor del som hans likedelingsmidler (800 000) utgjør av summen av det han eier, dvs. $(800000+400000=1200$ 000). Vi setter altså 800000 over brøkstreken og 1,2 millioner under brøkstreken. Likedelingsmidlene utgjør dermed 2/3 deler av det han eier. Det betyr at han kan trekke 2/3 av studielånet fra på skiftet, dvs. ca. 66000 kroner av studielånet.

Ikke all forbruksgjeld skal trekkes fra med en forholdsmessig del selv om ektefellen faller inn under $\S$ 58 tredje ledd. Dersom forbruksgjelden eksisterte allerede ved ekteskapsinngåelsen, kan det tenkes at restforbruksgjelden kan trekkes fra fullt ut i likedelingsmidlene, se neste punkt.

\subsection{Forbruksgjeld stiftet før ekteskapet}

Skjevdelingskravet er et nettokrav - opprinnelig gjeld skal trekkes fra før skjevdelingskravet beregnes etter $\S 59$ første ledd. Hvis noe av forbruksgjelden fremdeles står til rest på skiftetidspunktet, oppstår spørsmålet om restgjelden skal trekkes fra på skiftet fullt ut (tredje ledd bokstav a) eller med en forholdsmessig del (tredje ledd bokstav c). Problemet kan belyses med et eksempel:

La oss tenke oss at hustruen ved ekteskapets inngåelse eide en leilighet verdt 2 millioner kroner som var fullt nedbetalt ved ekteskapsinngåelsen. Samtidig hadde hun ved inngåelsen et studielån på 400000 kroner som hadde gått til forbruk. Fire år etter bryllupet blir hun skilt, og krever skjevdeling. Boligen er fremdeles verdt det samme, mens studielånet er redusert til 300000 kroner - hun har nedbetalt 100000 kroner av lånet med inntekten sin under ekteskapet. Vi forutsetter at dette er alt hun eier. Hennes skjevdelingskrav blir da på 1,6 millioner ( 2 millioner kroner minus opprinnelig gjeld på 400000 kroner). Som følge av at hun gikk inn i ekteskapet med gjeld, blir altså en del av skjevdelingsformuen omdannet til likedelingsmidler, selv om formuen altså stammer fra tiden før ekteskapet. Det må da være klart at restgjelden på 300000 kroner kan trekkes fra fullt ut etter $\S 58$ tredje ledd bokstav a. Gjelden ble riktignok ikke direkte brukt til å erverve eller påkoste likedelingsmidler, men til en reduksjon av skjevdelingsmidlene på skiftet som må likestilles med dette da det har samme virkning. Forbruksgjelden medførte nemlig at en tilsvarende del av boligformuen ble omdannet til likedelingsmidler. Fordi hustruen hadde studielånet på 400000 kroner ved inngåelsen av ekteskapet, får hun ikke skjevdelt hele boligens verdi. Skjevdelingskravet er et nettokrav, og forbruksgjelden skal trekkes fra før skjevdelingskravet beregnes. ${ }^{9}$ Studielånet medfører altså at $\mathbf{4 0 0} 000$ kroner av boligens verdi er gjenstand for likedeling. Forbruksgjelden blir på skiftet da brukt til noe som må likestilles med «erverv» av likedelingsmidler, og vilkåret i bokstav a er dermed

\footnotetext{
${ }^{9}$ Hvorvidt forbruksgjeld skal trekkes fra med nominelt beløp eller også redusere andelen av verdistigningen på andre gjenstander, settes ikke på spissen i eksempelet her siden boligen ikke har endret verdi i løpet av ekteskapet. Se nærmere om dette spørsmålet i Sverdrup, «Likheter og forskjeller mellom særeie og skjevdeling», FAB 3/2013 pkt. 5.3.
} 
oppfylt. Dersom hun bare får trukket fra en forholdsmessig del av forbruksgjelden etter $\S 58$ bokstav c, blir hun rammet dobbelt opp. Forbruksgjelden har for det første medført at hun må likedele formue som ellers ville blitt holdt utenfor delingen. Hvis noe av den samme gjelden skulle belastes den resterende skjevdelingsformuen, blir den i realiteten trukket fra to ganger. Ser vi nærmere på regnestykket, oppdager vi også at resultatet stemmer med grunntanken bak formuesordningen. Det går 100000 kroner til likedeling fra henne, hvilket tilsvarer nøyaktig det beløpet som er skapt under ekteskapet i denne saken, dvs. inntekten som ble benyttet til nedbetaling av forbrukslånet.

\section{Skjevdelingskrav}

\begin{tabular}{lllr} 
Boligens verdi & & kr & 2000 \\
$\begin{array}{l}\text { - Opprinnelig gjeld (studielånet) } \\
\text { Skjevdelingskrav §59.1 }\end{array}$ & & kr & 400 \\
& & kr & 1600 \\
Brutto rådighetsdel & kr & 2000000 \\
- Skjevdelingskrav & kr & 1600000 \\
- Gjeldsfradrag, §58. 3. a & kr & 300000 \\
\hline Netto rådighetsdel & kr & 100000 \\
\hline
\end{tabular}

Den samme problemstillingen oppstår for øvrig for dem som måtte mene at skjevdelingskravet reduseres når en skjevdelingseiendom (f.eks. et arvet hus) pantsettes som sikkerhet for et forbrukslån under ekteskapet. Da må forbrukslånet som står til rest på skiftetidspunktet, fullt ut føres til fradrag på skiftet etter tredje ledd bokstav a med den samme begrunnelse som angitt ovenfor: Forbrukslånet er benyttet til å omdanne skjevdelingsverdier til likedelingsmidler på skiftet, og det må likestilles med «erverv». Etter mitt syn oppstår imidlertid ikke dette spørsmålet. Jeg er av den oppfatning at skjevdelingskravet ikke reduseres som følge av at skjevdelingseiendommen senere pantsettes som sikkerhet for forbrukslån. Så lenge den pantsatte skjevdelingseiendommen fremdeles eies av ektefellen, finnes det verdier som «klart kan føres tilbake til» arv mv., jf. § 59 første ledd. Først når pantet realiseres til dekning av forbrukslånet, er skjevdelingsretten tapt. ${ }^{10}$ Dette stemmer også best med tankegangen bak reglene i § 58 hvor det avgjørende for gjeldsavleggelsen er hva lånet er benyttet til å finansiere - og ikke hvorvidt lånet er sikret med pant i bestemte eiendeler. Men for Holmøy og Lødrup oppstår spørsmålet ettersom forfatterne gir uttrykk for at skjevdelingskravet reduseres når skjevdelingseiendommen er pantsatt som sikkerhet for forbrukslån. ${ }^{11}$

\footnotetext{
${ }^{10}$ Sverdrup, «Skjevdeling på felleseieskifte - noen uavklarte spørsmål», i Bull, Hagstrøm og Tjomsland (red.), Bonus Pater Familias. Festskrift til Peter Lødrup, Oslo 2002, s. 688.

${ }^{11}$ Holmøy og Lødrup, Ekteskapsloven og enkelte andre lover med kommentarer, 2. utgave Oslo 2001, s. 391 og s. $393 \varnothing$ øerst.
} 


\section{Solidargjeld og ansvaret innad}

Når det først er klarlagt at en gjeldspost kan trekkes fra på skiftet - enten med hjemmel i § 58 annet eller tredje ledd - oppstår et nytt spørsmål i saker hvor begge ektefeller er solidarisk ansvarlige for gjelden. Er det det beløpet som tilsvarer gjeldsansvaret utad, dvs. overfor kreditor, som skal trekkes fra, eller er det ansvarsbeløpet innad mellom ektefellene? Ettersom en ektefelle ved solidaransvar risikerer å måtte dekke hele gjelden og ikke bare det som måtte falle på vedkommende etter det interne forholdet mellom dem, kunne man kanskje tenkt seg at hver ektefelle også fikk trekke fra hele lånebeløpet, men i § 58 første ledd annet punktum slås det fast at det bare er beløpet som motsvarer ansvaret innad som kan trekkes fra: «Er ektefellene sammen ansvarlig for gjeld, kan hver gjøre fradrag for den delen som faller på ham eller henne etter forholdet mellom ektefellene. " Fordi begge ektefeller her løper en risiko for å bli krevd for hele beløpet av kreditor, gis ektefellene i el. § 64 hjemmel for å kreve at den andre ektefellen betaler eller sikrer midler til dekning av den del av gjelden som faller på vedkommende etter de underliggende forhold. Regelen i § 64 endrer ikke det beløpsmessige resultat av skifteoppgjøret, men minsker risikoen for senere å bli krevd for gjeld man egentlig ikke skulle ha dekket.

Regelen i § 58 første ledd annen setning om at det er gjeldsansvaret innad som er avgjørende for hvilket beløp som kan føres til fradrag, gir ingen selvstendig hjemmel for gjeldsavleggelse, men utdyper bare fradragsreglene som finnes i annet og tredje ledd. Systematisk burde vel denne bestemmelsen kommet sist i paragrafen. Slik den er plassert helt først, kan den lede noen til å tro at det her gis en selvstendig hjemmel for gjeldsavleggelse. Men hjemmelen for gjeldsavleggelse må alltid finnes enten i annet eller tredje ledd - det sies for $\varnothing$ vrig uttrykkelig i første ledd første punktum.

Bestemmelsen i § 58 første ledd regulerer bare tilfeller hvor begge ektefeller er solidarisk ansvarlige for gjelden. Hva gjør man så i tilfeller hvor bare den ene ektefellen er ansvarlig overfor kreditor, men hvor begge er innad ansvarlige for gjelden? La oss tenke oss at ektemannen er eneansvarlig overfor kreditor, men at konen er medansvarlig innad for lånet. Ektemannen kan da føre hele gjeldsbeløpet til fradrag på skiftet dersom det finnes hjemmel i § 58 annet eller tredje ledd. Men ektemannen har samtidig en fordring på konen som i utgangspunktet tilsvarer hennes interne gjeldsansvar. Dette er en aktivapost som øker hans brutto rådighetsdel. Konen vil ha en tilsvarende gjeldspost for sin del av det interne ansvaret som hun eventuelt kan føre til fradrag på skiftet hvis det er hjemmel for det i § 58 annet eller tredje ledd.

\section{Oppsummering}

Regnskapsmessig ser det verdimessige skifteoppgjøret slik ut for hver av ektefellene:

Brutto rådighetsdel, dvs. verdier ektefellen eier som er felleseie (verdsettes i §§ 60 og 69)

- Forloddskrav etter $\S 61$

- Skjevdelingskrav etter $\S 59$

$=$ Delingsgrunnlaget 
- Gjeldsfradrag etter $\S 582$. ledd eller 3 . ledd litra a og b

$=$ Netto rådighetsdel $f \varnothing r$ «bokstav c-gjeld»

- «Bokstav c-gjeld» $x$ NR før «bokstav c-gjeld»

NR før «bokstav c-gjeld» + Skjevdeling + Særeienetto

= Netto rådighetsdel - NR1 (aldri mindre enn null)

De to netto rådighetsdelene - NR1 + NR2 - legges sammen og deles på to, jf. § 58 første ledd.

Gjeldsavleggelsen bygger på to prinsipper: dekningsprinsippet og finansieringsprinsippet. Vi har sett at dekningsprinsippet er uten unntak - det skal aldri gå en krone til likedeling fra en ektefelle før vedkommende har dekning for all sin gjeld. Har man kommet til at en ektefelle har positiv netto rådighetsdel samtidig som noe av gjelden ikke er dekket opp, enten i likedelingsmidler eller i særeie og skjevdelingsmidler, er bestemmelsene i § 58 anvendt feil. Finansieringsprinsippet har derimot flere unntak, blant annet som følge av at dekningsprinsippet skal være unntaksfritt.

Vi har sett at en ektefelles gjeld har betydning både for størrelsen på skjevdelingskravet etter $§ 59$ og gjeldsavleggelsen etter $\S 58$. Det kan være snakk om den samme gjeldsposten, men på ulike tidspunkter. Når vi skal beregne skjevdelingskravets størrelse, er det den opprinnelige gjelden som er av interesse, dvs. den gjelden som ektefellen hadde ved ekteskapsinngåelsen, eller den gjelden som måtte overtas eller tas opp som følge av at ektefellen mottok arv eller gave under ekteskapet. Størrelsen på denne opprinnelige gjelden har interesse fordi skjevdelingskravet er et nettokrav, slik at opprinnelig gjeld må trekkes fra for å komme frem til kravets størrelse. For gjeldsavleggelsen etter $\S 58$ er det derimot den aktuelle restgjelden på skiftetidspunktet som har interesse - det er bare dette beløpet som kan føres til fradrag etter $\S 58$. Som vi har sett flere eksempler på, er det en nær sammenheng mellom de to gjeldsbeløpene; det faktum at den opprinnelige gjelden er trukket fra før skjevdelingskravet beregnes, påvirker hvordan restgjelden skal behandles på skifte etter gjeldsavleggelsesreglene i § 58. Et gjennomgående trekk er at slik restgjeld skal trekkes fra fullt ut på skifte etter $\S 58$ tredje ledd bokstav a, da gjelden i realiteten er benyttet til «å erverve» likedelingsmidler på skiftet. En gjenstand, for eksempel et arvet hus, hvor ektefellen har måttet overta gjelden for å motta arven, vil i praksis bestå av både skjevdelingsmidler og likedelingsmidler. Gjeldsavleggelsen blir deretter. Restgjelden på det arvede huset har per definisjon gått til finansiering av likedelingsdelen av huset, og skal derfor trekkes fra fullt ut på skiftet etter $\S 58$ tredje ledd bokstav a. Det samme er tilfellet for den forbruksgjelden som ektefellen hadde ved ekteskapets inngåelse som samtidig reduserte den inngangsformuen som skulle skjevdeles, se pkt. 5.4 ovenfor.

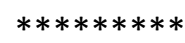

